\title{
Carbon Tax Implications On Corporate Social Investment In The South African Motor Vehicle Manufacturing Industry
}

Suren Pillay, North West University, South Africa

Pieter W. Buys, North West University, South Africa

\begin{abstract}
Carbon excise tax was implemented on all passenger motor vehicles in South Africa as of 1 September 2010. Since its implementation, the impact of carbon tax on the corporate social investment (CSI) initiatives and expenditure of South African motor vehicle manufacturers has not been assessed. Given that the carbon tax price should ideally compensate for the damage caused by carbon emissions on the environment and people, the key knowledge gap this article aims to consider is whether the implementation of such a carbon tax is likely to affect the CSI decisionmaking process in respect of motor vehicle manufacturers in South Africa.
\end{abstract}

The research methodology applied in this study is in the form of both a literature review and empirical research. A literature review was performed on the history, emergence and significance of CSI expenditure within the South African context. The empirical research includes an exploratory case study into the impact of the tax in the decision-making processes with regard to CSI expenditure, as well as the impact of carbon tax on CSI spending by motor vehicle manufacturers in South Africa. It was found that although the advent of carbon tax in the industry would place added pressure on the financial performance of the companies, it is unlikely that it would adversely affect the industry's commitment to the CSI initiatives.

Keywords: Carbon Taxation; Climate Change; Corporate Social Investment; Corporate Responsibility

\section{INTRODUCTION}

\section{Background}

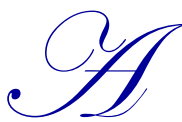

ccording to Hahn (2008:2), the European Commission defines corporate responsibility as a concept whereby companies integrate social and environmental concerns into their business operations. As such, it is closely related to the concept of sustainable development (Mirflazi, 2008), which puts the social, economic and environmental aspects of a company at the centre of its focus (Hahn, 2008). In support hereof, integrated reporting has been defined as written communication about how a company's strategy, governance, performance and prospects can contribute to the creation of value over the short, medium and long terms (IIRC, 2013). Integrated reporting has also been referred to as the integration of corporate responsibility reporting into existing financial reporting models to allow the users of such information to reflect on the social, environmental and economic impacts of the organisation (IRC, 2013; KPMG, 2011:2), thereby allowing for greater transparency and governance while promoting sustainable value creation (Buys, Van Rooyen \& Bosman, 2009).

A key factor in an organisation's ability to sustain value is found in the concept of sustainable development, which can be defined as meeting the needs of the present without compromising the ability of future generations to meet their own needs (Strange \& Bayley, 2008:27; Newport et al., 2003). Brent et al (2009), however, states that there is evidence that liberalized trade and increased incentives for exports from developing countries (such as South Africa) lead to greater exploitation of natural resources. The value of sustainable 
development lies in ensuring the wellbeing of humanity by promoting social and economic development, together with environmental conservation and protection (HREA, 2013). The core of sustainable development therefore requires the consideration of its three pillars - society, economy and environment (Strange \& Bayley, 2008:27; Newport et al., 2003), also referred to as the triple bottom line (TBL). The concept of sustainable development therefore provides a guiding framework for global development which, in turn, provides guidelines for good corporate responsibility.

\section{The Concept of Corporate Responsibility}

The broader concept of corporate responsibility is concerned with treating all the stakeholders of the company in an ethical and responsible manner, where the terms 'ethical' and 'responsible' translate into treating stakeholders in a manner that is deemed to be acceptable in civilised societies (Scott, 2007:32). It is important to note that the concept includes environmental considerations not only required by law and regulations, but also going beyond mere compliance to such laws and regulations, such as the private provision of public goods and the voluntarily internalization of externalities (Lyon \& Maxwell, 2008). Often, the outcomes of research into corporate responsibility-related topics have confirmed positive relationships between financial performance and social responsibility, with the implication that management should take such responsibility implications into account in their business decision-making (Chen, 2011; Margolis \& Walsh, 2003).

A company's overall corporate responsibility strategy may be further broken down into three key components or building blocks: 1) corporate financial responsibility, 2) corporate environmental responsibility, and 3) corporate social responsibility (Harvard, 2013; Mirflazi, 2008) as shown in Figure 1.

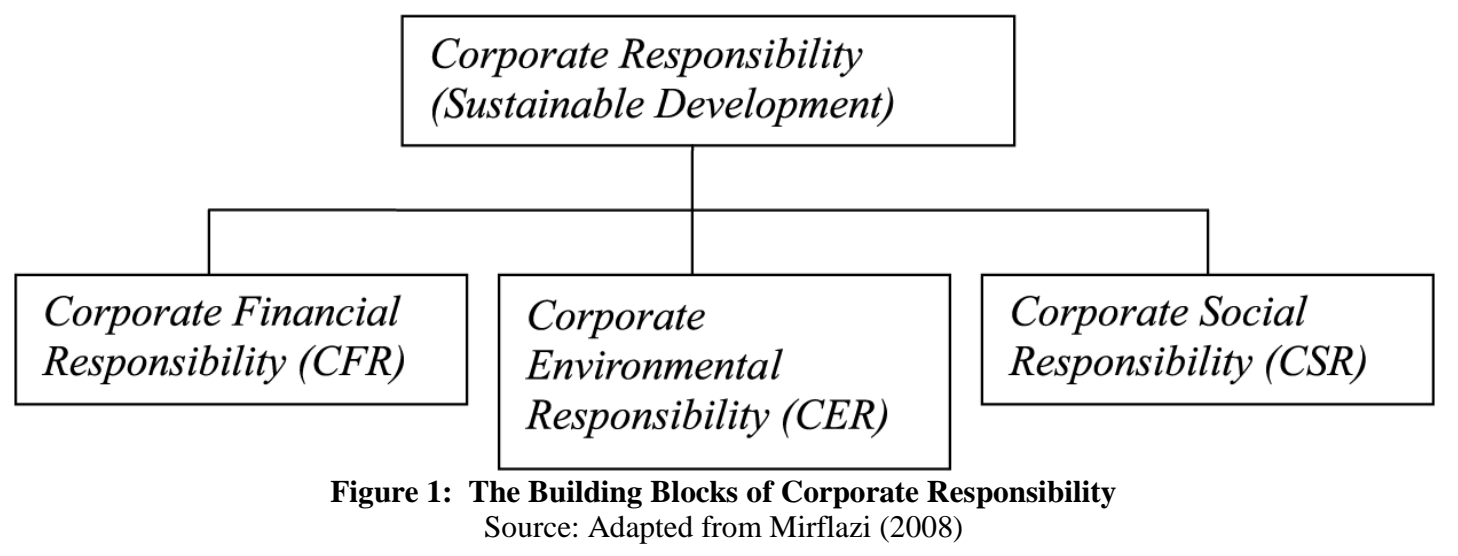

Although very much inter-related, Harvard (2013) and Mirflazi (2008) do identify distinct focus differences between the corporate financial responsibility, which deals with the efficient management of capital and the effective utilisation of corporate assets, corporate environmental responsibility, which attempts to reduce the adverse effects of environmental problems, and corporate social responsibility, which deals, inter alia, with how a company manages its relationships in key spheres of influence such as the workplace, marketplace, community and public policy realms.

\section{The Concept of Corporate Social Investment}

Within the South African corporate responsibility (or sustainable development as per Mirflazi (2008)) context, companies have reacted more positively to the concept of investment as opposed to the concept of responsibility, which could have been perceived as linking them to discriminatory practices of the past. The concept of corporate social investment (CSI) therefore suggests that a business-oriented outcome is often preferred over doing something because it is vaguely ethical (Skinner \& Mersham, 2008). CSI, as such, encompasses company projects that are external to the ordinary business activities and do not specifically have a profit motif. Rather, such projects would utilise company resources to the benefit and upliftment of various communities within the broader society (CSI, 2012). Whereas the terms corporate social investment and corporate social responsibility (or CSR) 
were previously often interpreted interchangeably, they should, in effect, be defined separately with the latter referring to the organisation's total responsibility towards the business environment and the former being considered as a sub-component thereof, aiming to uplift communities in such a way that the overall quality of life is improved (CSI, 2012).

According to Brent et al (2009), South Africa's climate change strategy sets out to reduce the rate of increase in greenhouse gas emissions by 2020 and then to stabilize such emissions for ten years, after which it would aim to reduce the emissions in absolute terms. As part of the South African government's effort to manage greenhouse gas emissions, a carbon excise tax was introduced on all new passenger motor vehicles manufactured from 1 September 2010 (Shirley, 2010; NAAMSA, 2011). The purpose of a carbon tax is to internalise externalities related with anthropogenic climate change (Nel \& Du Plooy, 2013; Metcalf, 2009). Carbon tax is a market-based instrument that creates a cost to emissions directly by taxing the carbon content of fuels (Hasset et al, 2007). The social cost of carbon (SCC) has been defined as the amount of damage caused by each additional tonne of greenhouse gas emitted into the atmosphere (Hardisty, 2009). Any carbon tax should, in terms of cost-benefit analysis, therefore be equal to the marginal damage caused by greenhouse gas emissions at the point where marginal damage equals marginal cost (Pearce, 2003). However, there are other aspects that must also be considered, other than the direct social cost of carbon. Indirectly, many companies do re-invest much of their resources and profits into social upliftment initiatives. By placing additional pressure on such companies' financial performances, their ability (and perhaps even willingness) to contribute to CSI initiatives may be adversely affected.

\section{RESEARCH OBJECTIVES AND METHODOLOGY}

Considering the above and given the potential impact of carbon taxes on private companies' CSI initiatives, this paper aims to explore the potential impact of carbon tax implementation on such initiatives and expenditure for motor vehicle manufacturing companies in South Africa. The primary research question under consideration could therefore be formulated as "Is the implementation of carbon tax likely to adversely affect the CSI initiatives and expenditure of the motor vehicle manufacturers in South Africa?"

In addressing the above question, two basic high-level objectives are set. Firstly, the development and impact of CSI within the South African context has to be considered and secondly, the commitment of the motor vehicle manufacturers to their CSI initiatives and expenditure, in light of the additional carbon tax burden facing them, should also be considered. This research project is also conducted as a case study. According to Van Wynsberghe and Khan (2007), case study research has been defined as a trans-paradigmatic and trans-disciplinary heuristic that involves careful explanation of the occurrences for which substantiation is being collected. Such research promises benefits in terms of developing internally valid and context-sensitive measures of concepts (Bennett \& Elman, 2006).

With regard to the literature research, a review of the emergence of CSI in South Africa is conducted, followed by a consideration of the welfare effect of such social investment within the context of corporate responsibility and sustainable development. The economic significance of the South African motor vehicle industry, and its contribution to CSI, is also considered. The empirical research component focused on the potential impact of carbon tax on the CSI policies and strategies of the South African motor vehicle manufacturers. The sample characteristics of the respondents include multinational motor vehicle manufacturers within the boundaries of South Africa that are subject to carbon excise tax on motor vehicles sold to the general public. There are a total of eight companies meeting these requirements, of which four were willing to participate in the study. The research questionnaire was developed based on the underlying literature study and consisted of ten questions, utilising an appropriate four-point Likert-type response scale as well as a quantification of actual CSI initiatives and expenditure for the years 2009-2012. The period 2009-2012 allowed for the evaluation of the before and after impact of carbon tax (being implemented from 2010) on CSI initiatives and expenditure, as well as to provide corroborative evidence to answers in response to questions included in the questionnaire. The researcher was available during the survey to provide guidance and clarification in case the respondents had questions regarding the questionnaire.

In order to meet its objectives, the questionnaire had three objectives, namely i) to determine the current perception of the meaning and value of CSI by the respondents ii) to determine the respondents perceptions of the 
welfare effect of carbon tax, and iii) to evaluate the impact of carbon tax on the company CSI initiatives and expenditure.

\section{CORPORATE SOCIAL INVESTMENT RELEVANCE IN SOUTH AFRICA}

\section{Introduction}

The sections that follow examine the impact of carbon tax on CSI under the assumption that the carbon tax price correctly reflects the monetary damage caused by carbon emissions. The impact of carbon tax on CSI is analysed by first considering the emergence of CSI in South Africa and then evaluating the contribution of the South African motor vehicle manufacturers to CSI initiatives within South Africa.

\section{CSR and CSI Emergence in South Africa}

Even though CSR principles may be traced to the 1800s, with Adam Smith's book entitled The Wealth of Nations, first published in 1776, the emergence of globalisation in the 1980s and 1990s resulted in greater environmental awareness and the development of responsible business practices (SSA, 2012). Companies within South Africa may also benefit in terms of financial performance and competitiveness by implementing welldesigned CSR strategies, as a recent study of emerging markets (which included South Africa) confirmed that proactive CSR strategies combined with generating quantitative extra financial information to shareholders and regulators is an emerging driver of global competitiveness in respect of industrial organisations (Segot, 2011). The background to the emergence of CSI in South Africa lies in performance-based CSR measures, which have been adopted in many developing countries with specific accountability ratings having been applied at various times (Ndlovu, 2011).

Following the implementation of the Black Economic Empowerment Act of 2003 in South Africa, there has been increased pressure on companies to play a greater role in generating development goals (Ndlovu, 2011). The guidelines of the Black Economic Empowerment Act formalise CSR programmes and allow its results to be more easily communicated (CSR, 2012). The South African government's commitment to encourage corporate responsibility is also evidenced by the Codes of Good Practice, which were finalised on 9 February 2007 and aim to ensure consistency in the implementation of socially responsible behaviour in the area of empowerment of historically disadvantaged population groups (Arya \& Bassi, 2011). The overall concept of corporate responsibility is also further encouraged in South Africa by the following (CSR, 2012):

- $\quad$ The South African Constitution (drafted in 1994) and reforms of the existing legislature have allowed for social and environmental topics to be focused on by companies.

- The scarcity of skilled employees in certain areas of expertise in South Africa has resulted in the creation of specialised training programmes that various companies may sponsor.

- $\quad$ The HIV problem in South Africa has allowed for greater involvement of South African companies in the field of healthcare.

It should be noted, however, that CSI is specific to South Africa and that it is (arguably) driven primarily by legislation and industry charters (Hinson \& Ndlovu, 2011). However, Hinson and Ndlovu (2011) also note that it promises to present a new way of addressing developmental problems in South Africa. Following the emergence of CSI in South Africa in 2004, the Johannesburg Stock Exchange (JSE) launched the first Socially Responsible Investment (or SRI) index, which contains a listing of companies on the FTSE/JSE All Share Index that have met certain criteria in respect of socially responsible performances (JSE, 2012). The popularity of the SRI index among companies can be measured in terms of compliance to the relevant guidelines and frameworks, such as the JSE's integrated reporting requirement or the Global Reporting Initiative (GRI) framework, for example. According to SSA (2011), the annual 2011 SRI index review (which reviewed 109 JSE-listed companies) found that approximately two-thirds of the JSE-listed companies assessed by a JSE-appointed global investment research provider had fulfilled the requirement to become a constituent of the JSE's SRI index as at December 2011.

With regard to social sustainability, Cronje and Chenga (2009:416) suggest that social dimension of sustainable development encompasses the transformation and perpetual improvement of the livelihoods of people 
with in a specific social context. According to Haman (2003), such responsibility of social sustainability can also be framed in terms of social investment as it effectively requires a company to respond to communities and the general public on issues such as human rights and employee welfare.

\section{The South African Motor Vehicle Manufacturer's Role in CSI}

The national contribution of South African companies to CSI initiatives is significant, with Thwaits (2012) indicating that up to R6.2 billion was spent in the areas of education, healthcare and community development for the 2010-2011 financial year. In an analysis of social investment expenditure by industry, CSI (2006) found that the manufacturing industry is currently the fifth largest contributor to the total CSI expenditure in South Africa.

Within the context of the South African manufacturing industry, the motor vehicle sector contributes approximately $7.5 \%$ to the country's total GDP and accounts for approximately $10 \%$ of the country's total manufacturing exports (SAI, 2008). Considering these numbers, it is little wonder that the government considers the motor vehicle industry as a key sector targeted for growing the country's economy. Within this context, the South African motor vehicle manufacturers have then also contributed in a significant manner to CSI initiatives. In terms of monetary investments, Volkswagen SA, for example, invested in excess of ZAR400,000,000 (U\$48,000,000) (VWSA, 2012; OANDA, 2013) and Mercedes Benz SA invested in excess of ZAR270,000,000 (U\$33,000,000) in CSI projects (MBSA, 2012; OANDA, 2013). Furthermore, according to Mossman (2010), the types of CSI projects typically receiving funding from the motor vehicle manufacturing industry include social upliftment initiatives focusing on:

- $\quad$ Education-related funding such as:

$\circ$ the Nelson Mandela Ndonga School and Clinic Project

○ the Technology Laboratory on the Mamelodi campus of Vista University

$\circ$ the BMW Mathematics Science and Technology Centres for Excellence

$\circ \quad$ the Mercedes-Benz Coastal Education \&Visitors' Centre

$\circ$ the Schools Start-up Programme for primary education in partnership with the Eastern Cape Department of Education

○ the Volkswagen Community Trust Socio-economic factors focusing specifically on education, youth development and job creation

- Healthcare funding for multiple HIV/AIDS and child healthcare centres such as:

0 the Soshanguve Health and Wellness Centre

the BMW LoveLife Youth Center against HIV/AIDS

the Siyakhana SME HIV \& Aids

the Hillcrest Aids Centre

the St Bernard's Hospice

the Mamelodi Hospice

the Trucking Against Aids Wellness Centre

the Baby Therapy Centre

- Environmental-related funding for initiatives such as:

$\circ$ the Schools Environmental Education Development (or SEED) project focusing on increasing environmental awareness among children

0 the Peace Parks Foundation

$0 \quad$ the World Wide Fund (WWF) bursary awarded to women from a rural community to study toward a qualification in natural resource management

Considering the above historical examples, it is clear that the motor vehicle manufacturers in South Africa have not been lax in their social investment initiatives in various South African communities. The question, however, is whether the advent of the additional burden of carbon taxes on their products may reduce their level of commitment to future social investment initiatives. 


\section{THE EFFECT OF CARBON TAX ON CSI INITIATIVES}

The sections that follow consider the potential impact of carbon tax on the CSI initiatives and expenditure of South African motor vehicle manufacturers. In order to address the research question and objectives as set out above, a questionnaire was submitted to the South African motor vehicle manufacturers. Table 1 represents an analysis of descriptive statistics associated with the responses received from the respondents.

Table 1: Analysis of Descriptive Statistics

\begin{tabular}{|l|c|c|c|c|}
\hline Question No & Min Statistic & Max Statistic & Med Statistic & Std Dev Statistic \\
\hline 1 & 3 & 4 & 3.67 & 0.58 \\
\hline 2 & 3 & 4 & 3.67 & 0.58 \\
\hline 3 & 4 & 4 & 4 & 0 \\
\hline 4 & 4 & 4 & 4 & 0 \\
\hline 5 & 4 & 4 & 4 & 0 \\
\hline 6 & 4 & 4 & 4 & 0 \\
\hline 7 & 2 & 3 & 1.67 & 1.53 \\
\hline 8 & 4 & 1 & 2.33 & 1.53 \\
\hline 9 & 4 & 1 & 2.33 & 1.53 \\
\hline
\end{tabular}

\section{Section 1: CSI Perception and Carbon Tax Compliance}

The first part of the questionnaire focused on the respondents' understanding of the concept of CSI, as well their overall level of compliance with carbon tax legislation. Question 1 enquired whether social investment is considered as a necessary cost of doing business, while Question 2 asked whether social investment gives a company a distinctive position in the market. Question 3 asked the respondents to confirm the definition of CSI as taking proper account of the broader interests of society when making business decisions. Question 4 posed an alternative definition of CSI, which is to sacrifice profits in order to do the right thing. Question 5 determined whether the respondents comply with all relevant carbon tax legislation and regulations.

- $\quad$ Question 1 (score: 3.67): The majority of the respondents strongly agree, without exception, that CSI is a necessary cost of doing business within the South African business context.

- $\quad$ Question 2 (score: 3.67 ): The majority of the respondents strongly agree, without exception, that CSI gives a company a distinctive position in the market.

- $\quad$ Question 3 (score:4): All of the respondents in the study confirmed the definition of CSI as taking proper account of the broader interests of society when making business decisions.

- Question 4 (score: 4): All of the respondents in the study confirmed an alternative definition of CSI as sacrificing profits in order to do the right thing.

- Question 5 (score: 4): All the respondents confirmed that they are in compliance with all carbon tax legislation and regulations.

\section{Section 2: Carbon Tax Pricing}

The second part of the questionnaire focused on carbon tax pricing and its relationship to their CSI initiatives and expenditure. Question 6 asked about the impact of carbon tax pricing on their CSI decision, while Question 7 enquired as to the respondents' opinions on whether carbon excise tax for motor vehicles is adequately priced and accurately reflects the associated damage cost from motor vehicle carbon emissions.

- Question 6 (score: 4): All of the respondents confirmed, without exception, that carbon tax pricing has no impact on their CSI initiatives and expenditure.

- $\quad$ Question 7 (score: 1.67): No specific conclusion could be made on whether carbon tax is being adequately priced and whether the carbon tax price accurately reflects the associated damage cost from motor vehicle carbon emissions, thereby indicating that there is some uncertainty among vehicle manufacturers as to whether carbon tax is adequately priced and accurately reflects the damage costs from motor vehicle carbon emissions. 


\section{Section 3: Impact of Carbon Tax on CSI Policy and Expenditure}

This section of the questionnaire focused on the impact of carbon tax on social investment and, in particular, whether the CSI budgets of the motor vehicle manufacturers were lowered since the inception of carbon tax. Question 8 asked whether the implementation of carbon tax affected their social investment policies and strategies. Question 9 is framed under the assumption that carbon tax is adequately priced and asked the respondents to confirm whether their obligations to society and the environment under CSI are effectively reduced as a result of the implementation of carbon tax. Question 10 required the respondents to quantify the CSI expenditure for the years 2009-2012 to determine the pattern of CSI expenditure both before and after the implementation of carbon tax.

- Questions 8 and 9 (score: 2.33 each): No specific conclusion could be made on whether the implementation of carbon tax has affected the CSI policy and strategy of the respondents. The average answer obtained for the question was mid-way between the two extremes. On a factual basis, however, $66.67 \%$ of the respondents do not agree, subject to exception, that carbon tax has affected the corporate social investment policy and strategy of the company.

- $\quad$ Question 10: Quantifications of actual corporate social investment expenditure from the 2009 to 2012 were requested from the respondents. The actual average corporate social investment expenditures, as received from the respondents, are presented in Figure 2:



Figure 2: Average CSI As Reported By the Respondents

The horizontal axis represents the year in review and the vertical axis represents the CSI expenditure. When considering the trend in the average CSI expenditure, as reported by the respondent (as illustrated in Figure 2), it would seem as if the implementation of carbon tax did not adversely affect the bigger picture in terms CSI expenditure. It should, however, be noted that the above is a presentation of the average CSI expenditure and that individual respondents may have different experiences than the above.

\section{DISCUSSION AND CONCLUSION}

The key aim of this paper was to consider the potential impact of carbon tax implementation on the social investment strategies and expenditure of motor vehicle manufacturing companies in South Africa. In answering the question of whether the implementation of carbon tax is likely to adversely affect the corporate social investment initiatives of the motor vehicle manufacturers in South Africa, two objectives were set. Firstly, it was indicated that the concept of corporate social investment shifts the focus from a responsibility perspective to a more constructive investment perspective. To that effect, the motor vehicle manufacturing industry became a major contributor to such social upliftment initiatives. 
In gauging whether the advent of a carbon tax had an effect on the revenue source for this industry, there may be a valid concern that the industry might limit (or plan to limit) their contribution to corporate social investment initiatives within the South African context, which has to be highlighted. Secondly, the commitment of the motor vehicle manufacturers to their corporate social investment strategies, in light of the additional carbon tax burden facing them, should be determined. To that effect, the respondents have indicated that they strongly agree, without exception, that corporate social investment is a necessary cost of doing business and that CSI gives a company a distinctive position in the market. All of the respondents in the study confirmed the definition of CSI as taking proper account of the broader interests of society when making business decisions as well as the practice of sacrificing profits in order to do the right thing. In addition, all of the respondents confirmed that they comply with all carbon tax legislation and regulations. In terms of the carbon tax pricing, all of the respondents confirmed, without exception, that carbon tax pricing has no impact on the CSI decision. No conclusion could be made on whether carbon tax was adequately priced and whether the carbon tax price accurately reflects the associated damage cost from motor vehicle carbon emissions. The responses indicated that there is uncertainty among motor vehicle manufacturers as to whether carbon tax is adequately priced and accurately reflects the damage costs from motor vehicle carbon emissions. Finally, no conclusion could be made on whether the implementation of carbon tax has affected CSI policy and strategy of the company. However, $66.67 \%$ of the respondents did not agree, subject to exception, that carbon tax has affected the corporate social investment policy and strategy of the company. No conclusions could be made on whether corporate obligations to environment and society under CSI would be reduced due to the implementation of carbon tax under the assumption that carbon tax is adequately priced.

Approximately $66.67 \%$ of the respondents do not agree, subject to exception, that corporate obligations to environment and society under CSI are reduced as a result of the implementation of carbon tax. A quantitative analysis of CSI expenditure incurred by two respondents confirms that CSI policy is non-responsive to the implementation of carbon tax and has not resulted in any decrease in CSI expenditure by motor vehicle manufacturers in South Africa.

\section{RESEARCH LIMITATIONS, CONTRIBUTION AND FUTURE RESEARCH}

Notwithstanding the fact that the sample size of the motor vehicle manufacturers could be seen as a limitation within the context of the case study, it does provide some important contributions in that it highlights that the industry is a major contributor to various CSI initiatives and that the advent of carbon tax does not seem to diminish its commitment to CSI initiatives. The possibility that the respondents are not representative of all multinational motor vehicle manufacturers in South Africa could not be ruled out and the study should be read within this context. A further limitation is that CSI expenditure may well be driven by other factors, such as economic environment, company financial performance, and changes in company advertising policy, which is not necessarily within the scope of the study. It has been noted that CSI is specific to South Africa and that it promises to present a new way of addressing developmental problems in South Africa. Within this context, if CSI is successful in changing the way companies conduct their business, further research will have to be conducted on whether this will be sufficient to attract further foreign direct investment.

As far as future research opportunities regarding the impact of carbon tax on corporate social investment are concerned, the following may be considered. The National Treasury is expected to implement a national carbon tax in South Africa in 2015, which will affect most companies in South Africa. Company perception regarding the carbon tax price will become an even more important issue as it might well affect the financial bottom line of many companies. An empirical study carried out on the largest carbon emitters in the South Africa could reveal an impact of the new carbon tax on corporate social investment policy and expenditure.

\section{AUTHOR INFORMATION}

Suren Pillay is a Chartered Accountant (SA) and works at the Large Business Centre section of the South African Revenue Service (SARS) Kwazulu Natal. Suren is currently a PhD candidate at the North-West University in South Africa's Potchefstroom campus. This article is based on the research conducted for his PhD degree in Taxation. 
Professor Pieter W. Buys is currently the Research Program Leader at the North-West University (South Africa) and holds two PhDs (Accountancy and Management Accountancy), two Masters Degrees (MComm and MBA), and he is also a US Certified Management Accountant (CMA). E-mail: Pieter.Buys@nwu.ac.za (Corresponding author)

\section{REFERENCES}

1. Arya, B \&Bassi, B. (2011). Corporate social responsibility and broad-based black economic empowerment legislation in South Africa: Codes of good practice. Business and Society, 50(4): 674-695. December.

2. Bennett, A., \& Elman, C. (2006). Qualitative research: Recent developments in case study methods. Annual Review of Political Science, 9: 455-476.

3. Buys, P., Van Rooyen, S. \& Bosman P. (2009). Do socially conscious companies provide better financial performance? An exploratory study. Oeconomica, 54(1): 3-15.

4. Brent, A., Hietkamp, A, Wise, R. \& O'Kennedy, K. (2009). Estimating the carbon emissions balance for South Africa. South African Journal of Economic and Management Sciences, 12(3): 263-279.

5. Chen, H.C. (2011). The major components of corporate social responsibility. Journal of Global Responsibility, 2(1):85-99.

6. Cronje, F. \& Chenga, C.S. (2009). Sustainable social development in the South African mining sector. Development Southern Africa, 26(3): 416, September.

7. CSI. (2006). Are Corporate "Watchdogs" Failing to Bark. Available: http://www.givingandsharing.org.za/pages/Projects/Sarah\%20CAirns\%206\%20July\%2006.pdf Date of Access: 21 March 2012.

8. CSI. (2012). The what and why of CSI. Available: http://www.csisolutions.co.za/why-csi.php. Date of access: 28 December 2012.

9. CSR. (2012). The role of CSR in South Africa. Available: http://www.csrweltweit.de/en/laenderprofile/profil/suedafrika/index.nc.html Date of access: 28 December 2012.

10. Hamann, R. (2003). Mining companies' role in sustainable development: the why and how of corporate social responsibility from a business perspective. Development Southern Africa, 20(2): 237-254, June.

11. Hahn, R. (2011). Integrating Corporate Responsibility and Sustainable Development - A NormativeConceptual Approach to Holistic Management Thinking. Journal of Global Responsibility, 2(1): 8-22.

12. Hardisty, P.E. (2009). Analysing the role of decision-making economics for industry in the climate change era. Management of Environmental Quality: An International Journal, 20(2): 205-218.

13. Harvard, (2013). The Initiative Defining Corporate Social Responsibility. Available: http://www.hks.harvard.edu/m-rcbg/CSRI/init_define.html Date of access: 13 May 2013.

14. Hasset, K.A., Aparna, M. \& Metcalf, G.E., (2007). The incidence of U.S Carbon tax: A lifetime and regional analysis. (Working Paper 13554 prepared for the United States National Bureau of Economic Research). 42p.

15. Hinson, R.E. \& Ndlovu, T.P. (2011.). Conceptualising corporate social responsibility (CSR) and corporate social investment (CSI): the South African context. Social Responsibility Journal, 7(3): 332-346.

16. HREA, (2013). Sustainable Development. Available: http://www.hrea.org/index.php?doc id=444 Date of access: 7 May 2013.

17. IIRC, (2013). Integrated reporting. Available: http://www.theiirc.org Date of access: 7 May 2013.

18. IRC. (2013). Framework for the Integrated Reporting and the Integrated Report. (Discussion Paper issued by the Integrated Reporting Committee on 26 January 2011). 28p. (Unpublished).

19. JSE. (2012). Introduction to SRI Index. Available: http://www.jse.co.za/Products/SRI.aspx Date of access: 31.12.2012.

20. KPMG, (2011). Forward. Integrated Reporting: 1-24.

21. Lyon, T.P. \& Maxwell, J.W. (2008). Corporate Social Responsibility and the Environment: A Theoretical Perspective. Review of Environmental Economics and Policy, 1(0): 1-22.

22. Margolis, J.D. \& Walsh, J.P. (2003). Misery loves companies: rethinking social initiatives by business. Administrative Science Quarterly, 48(2): 655-89.

23. MBSA. (2012). Corporate Social Investment. Available: http://www.mercedes-benzsa.co.za/sustainabledevelopment/corporate-social-investment Date of access: 28 December 2012. 
24. Metcalf, G.E. (2009). Market based policy options to control US greenhouse gas emissions. Journal of Economic Perspectives, 23(2): 5-27.

25. Mirfazli, E. (2008). Evaluate corporate social responsibility disclosure at Annual Report Companies in multifarious group of industry members of Jakarta Stock Exchange (JSX), Indonesia. Social Responsibility Journal, 4(3): 388-406.

26. Mossman, J. (2010). Corporate Social Responsibility in the Modern World-System: A Case Study of German Automobile Corporations' Social and Environmental Responsibilities in South Africa. Cape Town: Stellenbosch University. (Dissertation - MA) $170 \mathrm{p}$.

27. NAAMSA see National Association of Automobile Manufacturers of South Africa.

28. National Association of Automobile Manufacturers of South Africa. (2011). Quarterly Review of Business Conditions: New Vehicle Manufacturing Industry. Pretoria. 6p.

29. Nel, R. \& Du Plooy, J. (2013). The role of tax incentives in reducing $\mathrm{CO}_{2}$ emissions - Evidence from vehicle manufactures. International Business and Economics Research Journal, 12(5): 551-564.

30. Ndlovu. T.P. (2011). Corporate Social Responsibility and Corporate Social Investment: The South African Case. Journal of African Business, 12(1): 72-92.

31. Newport, D., Chesnus, M. \& Lidner, A. (2003). The environmental sustainability problem ensuring that sustainability stands on three legs. International Journal of Sustainability in Higher Education, 4(4): 357363.

32. OANDA. (2013). Average exchange rates. Available: http://www.oanda.com/currency/ average Date of access: 21 March 2013.

33. Pearce, D. (2003). The social cost of carbon and its policy implications. Oxford Review of Economic Policy, 19(3): 362-384. November.

34. SAI. (2008). South Africa's Automotive Industry. Available: http://www.southafrica.info/business/economy/sectors/automotive-overview.htm Date of access: 17 March 2012.

35. Scott, S. (2007). Corporate Social Responsibility and the Fetter of Profitability. Social Responsibility Journal, 3(4): 31-39.

36. Segot, T.L. (2011). Corporate social responsibility as a bolster for economic performance: Evidence from emerging markets. Global Business and Organizational Excellence, 31(1): 38-53, November.

37. Shirley, B. (2010). South Africa: Carbon Tax to Add Thousands to Cars. Business Day. Available: http://www.businessday.co.za/Articles/Content.aspx?id=119959 Date of access: 28 December 2011.

38. Skinner, C. \& Mersham, G. (2008). Corporate social responsibility in South Africa: emerging trends. Society and Business Review, 3(3): 239-255.

39. SSA. (2011). South African listed companies make progress tackling Climate Change. Available: http://www.sustainabilitysa.org/SustainabilityInvestmentGuidelines/Corporateand InvestorsupportgrowsforJSEsSRI.aspx Date of access: 31 December 2012.

40. Strange, T \& Bayley, A. (2008). Sustainable development: Linking, economy, society and environment. OECD Insights: 1-146.

41. Thwaits, C. (2012). The GIBS Guide to Sustainability: Corporate Social Responsibility and Community Projects. Gordon Institute of Business Science, University of Pretoria.30p. (unpublished)

42. VWSA. (2012). Education. Available: http://www.vw.co.za/en/volkswagen groupsouthafrica/corporate citizenship/education.html Date of access: 28 December 2012.

43. Van Wynsberghe, R. \& Khan, S. (2007). Redefining case study. International Journal of Qualitative Methods, 6(2), Article 6. Available: http://www.ualberta.ca/ iiqm/backissues/6 2/vanwynsberghe.pdf Date of access: 17 July 2013. 